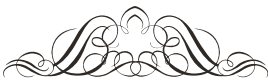 \\ Раздел 3. \\ Испания: международные связи
}

\author{
А. В. АВИЛОВА \\ ИСПАНИЯ И ЛАТИНСКАЯ АМЕРИКА: \\ ИМПЕРСКАЯ ТРАДИЦИЯ И СОВРЕМЕННОСТЬ
}

Aгнесса Викторовна Авилова, канд. экон. наук,
ИМЭМО РАН. avi@imemo.ru

Аннопация. Испанский варианп эволюции империи опличался оп «kлассического» брипанского: здесь произошел продолжипельныӥ разрыв опношениӥ бывших колоний с мепрополией. Однаkо сегодня Испания и спраны Аапинckoӥ Америки успешно развиваюп сопрудничеспво. Испания являепся одним из главных внешних инвеспоров в эпом регионе.

Ключевbе слова: Испания, Аапинская Америkа, имперская прадиция, преемспвенность.

Agnessa Avilova

\section{SPAIN AND LATIN AMERICA: IMPERIAL TRADITION AND CONTEMPORANEITY}

\begin{abstract}
The Spanish version of the evolution of the Empire differed from "classic" British: here there was a prolonged rupture of economic and political ties with the mother country. But now Spain and Latin American countries are developing cooperation in several directions. Spain is one of the major foreign investors for this region.
\end{abstract}

Keywords: Spain, Latin America, imperial tradition, continuity

Тема XI Конвента РАМИ «Диалектика империи: революция и преемственность» применительно к Испании может быть осмыслена как переход от имперской традиции, пережившей в XIX-XX вв. три промышленных революции, несколько буржуазных революций в Испании и череду освободительных движений в Латинской Америке, к современной культурно-исторической общности испаноязычного мира. Сегодня Испания и страны Латинской Америки развивают сотрудничество по многим направлениям, чему во все большей степени способствует процесс глобализации мирового рынка.

На некоторых этапах - например, в период мирного перехода от авторитарного режима Франко к демократии - Испания снова оказывалась в роли политической метрополии для 
стран латиноамериканского региона. Проблематика этого перехода, его формы и методы были созвучны тем процессам, которые развивались в Латинской Америке, и успехи испанского общества в восстановлении демократического правопорядка вызывали живейший интерес, открывая новые варианты модернизации.

Эволюция испанской империи на протяжении XVII-XIX вв., однако, существенно отличалась от более позднего, «классического» британского варианта. В свое время Британия, осознав историческую неизбежность утраты своих обширных колоний, подготовила и продвинула к управлению ими значительный слой местной элиты, ставшей надежной опорой сохранения устойчивых двусторонних связей. Британский капитал обеспечил дальнейшее развитие этих связей, экономически привязав и включив бывшие колонии в орбиту Британского Содружества наций

Отношения Испании с ее колониальными владениями развивались иначе. Как отмечает исследователь этой проблемы С. Дель Ареналь [1], испанские политики и интеллектуалы раннего периода освободительного движения в Латинской Америке не были готовы понять его причины и необратимый характер, оценить выдвинутую его вождем С. Боливаром идею культурно-политического объединения испаноязычных стран вокруг идеи общественного прогресса. Эта близорукость имела результатом полную и продолжительную потерю контактов образованной части испанского общества с новой латиноамериканской элитой. Равным образом и испанская буржуазия не сумела заложить основу для двусторонних экономических связей, которые помогли бы дальнейшему развитию сотрудничества. Только в 1830-х гг. была осознана необходимость установления дипломатических отношений со странами этого региона. Последовало признание Испанией латиноамериканских государств, начиная с Мексики (1836 г.) и кончая Гондурасом (1894 г.). Но отношения оставались холодными до враждебности, которая почти не скрывалась [1, p. 18-20]. В 1860-х гг. Испания трижды, с невыгодой для себя, пыталась вмешаться в латиноамериканские внутренние дела. Только в краткий период федералистской революции 1868 г. в испанском обществе возникло ощущение сближения со странами этого региона, окрашенное настроениями братства и республиканской солидарности.

Неразвитость двусторонних связей во многом объяснялась ослаблением международных позиций Испании после Венского конгресса 1815 г., наряду с ослаблением ее экономики, уже превратившимся в устойчивый тренд. Экономический упадок был обусловлен характером колониального хозяйствования Испании в Латинской Америке двумя веками раньше. Извлекая из своих владений огромные ресурсы (по оценке Ф. Броделя, за 1500-1650 гг. в Европу было вывезено 5 тыс. тонн золота и 60 тыс. тонн серебра), Испания не сумела использовать их для развития своей экономики, в то время как для ее соперников, прежде всего Англии, этот приток стал основой первоначального накопления капитала и резко ускорил рост международной торговли, а в скором будущем и промышленный переворот. Ф. Лист в классической работе 1841 г. «Национальная система политической экономии» отметил пагубное влияние, которое оказали общественный и религиозный порядкик, сложившиеся в Испании в период ее имперского могущества, на дальнейший ход развития ее производительных сил:

«Испания владела всеми элементами величия и благосостояния, когда фанатизм в союзе с деспотизмом начали подавлять великий дух нации. Это движение темной силы открылось изгнанием евреев и закончилось изгнанием мавров, вследствие чего два миллиона трудолюбивейших и богатейших жителей-промышленников были выброшены из Испании вместе с их капиталами. В то время как инквизиция прилагала все старания к изгнанию из страны туземной промышленности, она так же решительно препятствовала водворению в стране иностранных фабрикантов... национальной промышленности и могуществу был нанесен смертельный удар» [2, с. 75]. Тренд оказался продолжительным. «Способность создавать богатство бесконечно важнее самого богатства... этот народ постепенно утрачивал свои производительные силы» [2, с. 123-124], - заключает Ф. Лист.

Упадок экономики и внутриполитическая борьба оттеснили на второй план развитие отношений со странами Латинской Америки. Однако после потери последних колоний - Кубы, Пуэрто-Рико и Филиппин - в испано-американской войне 1898 г. проблема снова стала актуальной и подверглась переосмыслению. С установлением диктатуры Примо де Ривера (1923 г.) стала усиливаться идея ибероамериканской общности, превратившаяся в одну из главных установок внешней политики Испании. После прихода к власти Франко эта идея оформилась в виде Hispanidad -ультраконсервативной концепции, переосмысливавшей национальную идентичность как воплощение особой исторической миссии: Испания должна 
была вернуться к роли провиденциального начала, возрождающего империю если не территориально, то духовно․․ В политической программе Фаланги говорилось:

«У нас есть воля к империи. Мы утверждаем, что полнота Испании есть империя. Мы требуем для Испании выдающейся роли в Европе... В отношении Латинской Америки мы хотим унификации культуры, экономических интересов и власти» [1, p. 32].

Испанская церковь, со своей стороны, подчеркивала католическое содержание Hispanidad. Эта идеология, органично соединившая в себе фашизм, католический традиционализм и мессианское понимание национальной исторической судьбы, была взята на вооружение режимом Франко [1, p. 33].

Развитие событий внесло, однако, свои коррективы. Уже с конца 1950-х гг. Испания, подчиняясь влиянию развивавшейся в Европе интеграции, отказалась от автаркии и ориентировала свою экономику на включение в этот процесс, хотя в силу политических причин еще долго оставалась не принятой в Европейское экономическое сообщество. Официальное вступление Испании в ЕС произошло только в 1986 г. В странах Латинской Америки, где происходило ослабление авторитарных тенденций, также наметились интеграционные процессы и усилился интерес к европейскому хозяйственному опыту. Политические ограничения, затруднявшие развитие сотрудничества Испании с ЕЭС, способствовали, с другой стороны, ее сближению со странами Латинской Америки - особенно с Латиноамериканской ассоциацией свободной торговли. За 1960 -е гг. доля региона в испанском экспорте выросла с $8 \%$ до $13 \%$, а экспорт испанского капитала достиг 1 млрд долл. [1, p. 61].

Но настоящее сближение Испании как с ЕС, так и с латиноамериканскими странами началось после 1975 г. - в период демократизации, развивавшейся по обе стороны Атлантического океана. Этот процесс ускорил развитие сотрудничества по всему спектру экономических и политических отношений. Как отмечает С. Дель Ареналь, динамика этих отношений была неровной: если в годы правления ИСРП приоритетом для Испании была «Европа», то есть сближение с ЕС, то с приходом к власти Народной партии Аснара центр тяжести переместился на развитие отношений с США, а внимание к сотрудничеству с Латинской Америкой ослабло. Однако после 2004 г. доминирование европейского вектора вернулось, и вместе с ним возобновился активный интерес к испаноязычному миру.

Со второй половины 1990-х гг. Латинская Америка стала объектом беспрецедентной экспансии испанского капитала. Этому способствовала принятая в Испании «Программа модернизации государственного предпринимательского сектора», в рамках которой были приватизированы около 50 государственных компаний в стратегических отраслях (электроэнергетика, нефтегазовая промышленность, воздушный и морской транспорт, телесвязь, финансы), которые в скором времени превратились в крупные ТНК. Приватизация и структурные преобразования происходили и в Латинской Америке, что в ускоренном темпе открывало ее внутренний рынок для иностранного капитала. Эти встречные процессы имели результатом взрывной рост экспорта испанского капитала, и прежде всего - в Латинскую Америку. Если в 1980 г. прямые зарубежные инвестиции Испании составляли $1 \%$ ее ВВП, то в 2006 г - 41,4 \%. Две трети вывозимого капитала направлялось в Латинскую Америку. Пресса окрестила этот инвестиционный натиск «второй высадкой испанцев» на континенте [3]. По данным на 2011 г., Испания занимала второе место (после США) среди внешних инвесторов в регионе, ненамного уступая лидеру (14\% против $18 \%$ общего притока капитала) [4]. В 2015 г. она стала третьей (11,8\%), пропустив вперёд Нидерланды [5].

Испанский капитал устремился прежде всего в эксплуатацию природных ресурсов Латинской Америки и в сферу услуг (финансовый сектор, телекоммуникации, электро-газовая промышленность, добыча нефти и металлических руд, строительство) [6]. Более $80 \%$ вложений приходится на семь THK: Telefonica, REPSOL, IBERDROLA, ENDESA, Gas Natural de FENOSA, банки ВBVA и Santander [3].

В 2017 г. объем накопленных испанских инвестиций в Латинской Америке достиг 143,2 млрд евро, что составляет $31,4 \%$ совокупных прямых инвестиций Испании в мире. Накопленные латиноамериканские инвестиции в Испании также велики - 46,9 млрд евро и равняются $12,3 \%$ всех прямых иностранных инвестиций в этой стране. Испанский экспорт в страны Латинской Америки в 2016 г. достиг отметки 13,5 млрд евро [7]. Испания также - вторая после США страна, привлекающая латиноамериканских эмигрантов.

\footnotetext{
${ }^{1}$ Термин Hispanidad впервые в 1909 г. употребил М. де Унамуно, констатируя факт культурно-психологической близости испаноязычных стран.
} 
Нельзя, однако, не видеть, что, несмотря на впечатляющее восстановление связей между бывшими метрополией и колониями, роль и влияние Испании в Латинской Америке ограничены. Она исторически утратила возможность остаться доминирующей державой в своих бывших владениях. Сегодня Испания - это экономика средней величины, хотя и претендующая на глобальную значимость. Ведущей державой в Латинской Америке остаются США, для которых этот регион является зоной стратегических, политических и экономических интересов. Присутствие испанского капитала в регионе неравномерно: будучи наиболее заметным в Бразилии, Аргентине, Мексике и Чили, в остальных странах оно невелико. Ограничителем является и принадлежность Испании к ЕС, опосредующая ее связи с Латинской Америкой в таких важных аспектах, как аграрная и иммиграционная политика [1, p. 129]. В то же время, однако, принадлежность к ЕС служит и мостом, способным соединять интересы Испании и латиноамериканских стран; в этом находит одно из своих проявлений процесс глобализации, развивающийся в современном мире.

Имидж Испании в Латинской Америке постоянно меняется [8] - не только на больших исторических отрезках времени, но и в более узких временных рамках, на рубеже XX-XXI вв., когда в ее адрес зазвучали обвинения в «экономическом неоимпериализме», а также в зависимости от экономической ситуации в стране, в связи с переменами во внутренней и внешней политике. Однако повсюду в Латинской Америке сохраняется ощущение особой связи с бывшей метрополией. «В Ибероамерике знают, что если какая-либо страна в мире, например европейская, захочет помочь, то это будет прежде всего Испания» [8]. Постоянным и важным компонентом внешней политики Испании и стран Латинской Америки стали межправительственные совещания на высшем уровне. Развитие этих отношений служит подтверждением неослабевающей роли этнокультурного фактора в жизни современного общества.

\section{Литература / References}

1.Del Arenal C. Política exterior de España y relaciones con América Latina. - Madrid, 2011.

2.Лист Ф. Национальная система политической экономии. - М., 2005.

3.Multinacionales españolas [Electronic resource]. - Available at URL: omal.info.spip.php? page=imprimer\&id_ article $=4825$

4.Inversión extranjera directa [Electronic resource]. - Available at URL: omal.info/spip.php?article4822

5.España, tercer mayor inversor en América Latina y el Caribe [Electronic resource]. - Available at URL: www.cepyme/ es/2464-espana-tercer-mayor-inversor-america-latina-caribe

6.Doval Adán A. Historia reciente de las inversiones españolas en América. // Regional and Sectoral Economic Studies, 2014, Vol. 14-2. P.168.

7.Dastis A. España y América Latina, aliados preferentes [Electronic resource]. - Available at URL: http://www. eleconomista.es/especial-amercia/noticias/8392191/05/17/Espana-y-America-Latina-aliados-preferentes.html

8.Ayllon L. La imagen de España, en cambio continuo en América Latina [Electronic resource]. - Available at URL: http://www.abc.es/espana/abci-imagen-espana-cambio-continuo-america-latina-201610240753_noticia.html 